\title{
Palynological Study of OSE 1 Well in Offshore Niger Delta Basin: Implications for Age, Paleoclimate and Depositional Paleoenvironment
}

\author{
Osazuwa Abifade Ogbahon \\ Department of Applied Geology, The Federal University of Technology, Akure, Nigeria \\ Email: oaogbahon@futa.edu.ng
}

How to cite this paper: Ogbahon, O.A. (2019) Palynological Study of OSE 1 Well in Offshore Niger Delta Basin: Implications for Age, Paleoclimate and Depositional Paleoenvironment. International Journal of Geosciences, 10, 860-883.

https://doi.org/10.4236/ijg.2019.1010049

Received: May 29, 2019

Accepted: June 3, 2019

Published: October 11, 2019

Copyright ( 2019 by author(s) and Scientific Research Publishing Inc. This work is licensed under the Creative Commons Attribution International License (CC BY 4.0).

http://creativecommons.org/licenses/by/4.0/ (c) (i) Open Access

\begin{abstract}
Palynological study of 45 ditch samples from sedimentary successions penetrated by OSE 1 well located offshore western Niger Delta Basin was undertaken to determine the age of the sediment and reconstruct the paleoclimate and depositional paleoenvironment. All the analyzed samples were composited at $30 \mathrm{ft}$ from stratigraphic depth interval of 6330 to $9010 \mathrm{ft}$. The lithologic composition comprised mainly of brownish grey or light grey, finegrained shales with a gypsiferous horizon near the bottom. Palynological slides were prepared following standard palynological preparation procedures of sample maceration with hydrochloric $(\mathrm{HCl})$ and hydrofluoric $(\mathrm{HF})$ acids. The samples yielded moderately well-preserved, low to high diversity palynomorph assemblages of 58 taxa comprising 29 pollen grains, 9 pteridophic spores, 17 dinoflagellates, one acritarch, one freshwater algae and a fungi spore. The stratigraphic distribution of microflora assemblages was highly variable. The assemblage abundance was dominated by pollen and spores. The retrieved pollen grains included Monoporites annulatus, Sapotaceoidaepollenites sp. Psilatricolporites crassus, Psilatricolporites sp., Zonocostites ramonae, Retitricolporites irregularis, Monocolpites marginatus, Monocolpites sp., Pachydermites diederixi, Proxapertites cursus, Verrutricolporites rotundiporus, Striatopollis catatumbus, Retistephanocolpites gracilis, Echiperiporites estalae, Echiperiporites sp. and Inaperturopollenites sp. The retrieved spores included Magnastriatites howardi, Acrostichum aureum, Laevigatosporites sp., Polypodiaceoisporites sp., Verrucatosporites sp., Crassoretitriletes vanraadshooveni and Stereisporites $s p$. The recorded dinoflagellates included Achomosphaera sp., Andalusiella sp., Polysphaeridium zoharyi, Selenopemphix nephroides and Spiniferites sp. Leiosphaeridia $s p$. was the only acritarch
\end{abstract}


present in the assemblage. The freshwater algae was Botryococcus braunii. Fungi spore was present but not in significant amount. The stratigraphic interval was dated Early to Late Miocene (Burgidalian-Messinian) based on the occurrence and distribution of some stratigraphic fossil marker species including Magnatriatites howardi, Crassoretitriletes vanraadshooveni and Retistephanocolpites gracilis The abundant occurrence of pollen and spores typical of rain forest and freshwater swamp communities in the assemblage indicated tropical paleoclimatic conditions. The distribution pattern of Monoporites annulatus (Poaceae) and Zonocostites ramonae (Rhizophora) suggested seasonal fluctuations between dryer and wetter climatic conditions. The sediments were deposited in a wide range of environments including brackish lagoons, open salt water swamps, freahwater and nearshore to inner neritic settings.

\section{Keywords}

Niger Delta, Paleoclimate, Paleoenvironment, Miocene

\section{Introduction}

The Niger Delta Basin is of great economic importance because of its petroleum resource. Since 1956 when petroleum was discovered in commercial quantity in the basin, Nigeria's economy has gradually shifted from Agro-based to oil dependent. Today, roughly $80 \%$ of the nation's foreign exchange earnings derived from the sales of oil and gas. Exploration efforts for petroleum in the basin which began in 1937 were not rewarded until 1956 when the first producing well was drilled in Oloibiri field by Shell-BP. Nigeria joined the league of oil producing countries in 1958, with a modest daily production of 5100 barrels. The 1956 discovery of commercial quantity of petroleum in the Niger Delta Basin attracted the attention of many multinational oil companies and researchers to the region. Niger Delta petroleum province is ranked 11 globally in terms of petroleum resources, containing roughly $2.92 \%$ and $2.98 \%$ of the world-discovered oil and gas respectively [1]. Today, Nigeria's crude oil reserve, much of which occurs in the Niger delta Basin has remained stagnant at roughly 37 billion barrels of oil with a daily oil production of about 2.4 million barrels for nearly a decade as a result of ebbing exploration activities. The Federal Government in 2010 set a national target of $40 \mathrm{BBO}$ in reserve and a daily production of $4 \mathrm{MBO}$ per day by 2020 .

There have been considerable exploration activities in the basin and other sedimentary basins of Nigeria, especially since the discovery of oil in the delta. The delta has been covered with a dense grid of 2-D and 3-D seismic data and over 5000 wells have been drilled and developed [2]. Much of the crude oil is being mined from the conventional structural traps such as rollover anticlines, fault and diapiric traps within the Agbada Formation. This implies that much of the hydrocarbon trapped in subtle stratigraphic traps has yet to be discovered. If the national target is to be achieved, exploration efforts should be shifted to finding 
bypassed and deep-seated oil in these habitats. Sequence stratigraphy has proven to be an indispensable tool in petroleum exploration because of its ability to provide chronostratigraphic framework for the analysis and correlation of the lithic fills in basins that are deposited in response to sea level fluctuations, sediment supply and subsidence [3].

Although recent advances in seismic data acquisition techniques such as 3D seismic technology have led to the discovery of new giant hydrocarbon fields across the globe, yet the usability and effectiveness of seismic stratigraphy in petroleum exploration is hampered not only by its poor resolution in deep sedimentary basins but also by the high cost of interpretation of seismic data. As pointed out by [4], the science of petroleum exploration is multi-tool based, involving the integration of palynology with other geological disciplines such as geophysics, sedimentology, geochemistry and petrophysics with the ultimate goal of generating a geological model and elucidating on the petroleum system. The main applications of palynological analysis in petroleum exploration are chronostratigraphic correlation, evaluation of potential source rocks, reservoir rocks and sealing rocks, paleoenvironmental and sequence stratigraphic studies. Palynology is a useful stratigraphic tool in petroleum exploration applicable to sediments deposited in a wide range of depositional settings ranging from continental through coastal to shallow marine. [5], referencing [6] emphasized the use of fossil Rhizophora to Camptostemon ratio for sequence stratigraphic interpretations. According to them, [6] identified an inverse relationship in the occurrence trends of the two genera in relation to sequence stratigraphy, noting that the ratio of Rhizophora to Camptostemon is high during highstand system tract and low in lowstand system tract and transgressive system tract as a result, the sequential record of fossil pollen assemblages. Also, [4] demonstrated how the sequential record of fossil pollen assemblages can be used to study sea level oscillations and their phases, which can be related to particular depositional systems tracts. Although some of biostratigraphic studies have been carried out by several workers in the Niger Delta Basin including [7]-[14], the information they provide cannot be extrapolated over a long distance because of the very complex nature of stratigraphic architecture of the delta occasioned by the numerous synsedimentary faults which mainly deformed and compartmentalized the stratigraphic interval of interest, the Agbada lithostratigraphic unit. The availability of biodata from well to well will guarantee more accurate stratigraphic analysis thereby leading to the discovery of subtle hydrocarbon traps in the basin. It is the goal of this study therefore to utilize palynological analysis to erect biozones and reconstruct the depositional environment of the sedimentary succession penetrated by OSE-1 well (see Figure 1).

\section{Tectonic Setting and Stratigraphy of Niger Delta Basin}

The Niger Delta Basin is located in the Gulf of Guinea on the West African continental margin in the coastal area of Nigeria. It marks the southern limit of the 


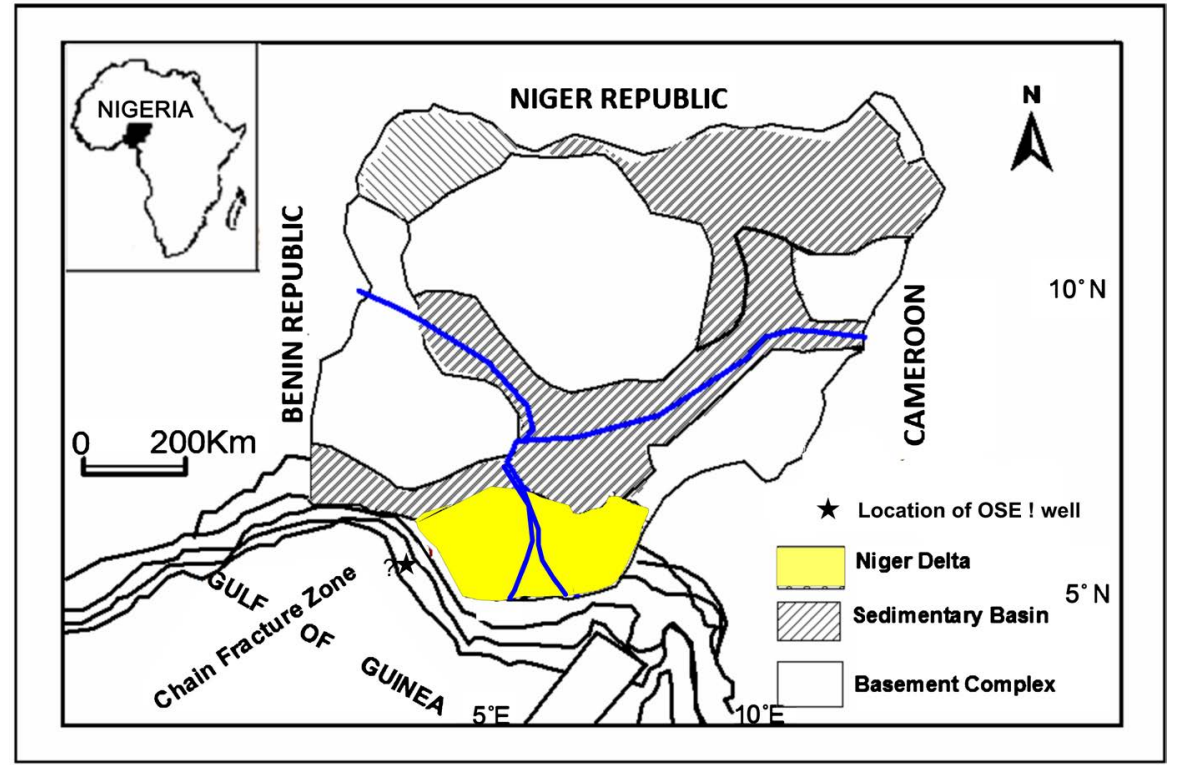

Figure 1. Sedimentary basins of Nigeria showing the location of Niger Delta Basin and location of OSE-1 well, modified after [1].

Benue Trough hence its evolution has been linked with that of this larger sedimentary complex [15]. The Benue Trough has been recognized as the failed arm of the three radial rift systems that met at an R-R-R triple junction in the Gulf of Guinea which was initiated in Early Cretaceous as a result of crustal doming [16]. The Niger Delta Basin represents the third phase in the evolution of the trough and its associated basins. The commencement of sedimentation during Aptian led to the evolution of the trough as the failed arm of a rift triple junction associated with the separation of South American and African plates. The second cycle from Santonian to Eocene began after the Santonian folding and thermo-tectonic event, leading to the formation of Anambra Basin and Afikpo Syncline.

The third phase from Eocene-Recent resulted in the formation of the Tertiary Niger Delta. The main depocentre is thought to have been located at the triple junction between the continental and oceanic plates [2]. The lithic fill of the basin consists of Paleocene to Recent siliciclastic deposits accumulated on both the faulted crustal blocks of the African continental margin and the oceanic crust [5] [17]. The delta has prograded southwestwards since the Eocene leading to the formation of major developmental stages including Central swamp I, Central Swamp II, Coastal Swamp II and Offshore depobelts. The accumulation of paralic sediments in each depobelt occurred in response to eustatic sea level oscillations active within the basin during the development of a depobelt [14]. The delta complex is deformed by well-developed growth faults and large-scale mud diapirs and its growth is closely related to the development of the diapirs [17].

The Niger Delta Basin contains an upward-coarsening regressive sequence of siliciclastic rocks roughly $12 \mathrm{~km}$ thick [18]. The lithic fill of the basin has been divided into three lithofacies namely Akata, Agbada and Benin Formations 
which were deposited in marine, transitional and continental environments, respectively. The three constitute a thick succession of progradational passive margin wedge. The Akata Formation (Paleocene-Recent) is the oldest and basal unit composed mainly of marine shales considered to be the main source rock in the basin [19]. It is composed of under-compacted marine sediments namely shales, clays, silts alongside lenses of sands deposited in front of the advancing delta. Its thickness ranges from 1968 to $19,680 \mathrm{ft}$ [20] [21]. These streaks of sand are thought to represent turbidites. The formation was deposited in prodelta to deeper marine settings. [22] stated that the formation was deposited in shallow to deep marine environments based on foraminifera evidence The formation is diachronous, ranging from Paleocene to Holocene. It outcrops offshore as diapirs along the continental slope, and onshore in the northeastern part of the delta, where it is characterized as Imo Shale [20].

The Agbada Formation is marked by alternating sandstone, siltstone and shale sequence with a thickness of over $3000 \mathrm{~m}$ [2]. Petroleum reservoirs in the basin occur as fine- to coarse-grained sandstone. These alternating clastics are the truly deltaic portion of the sequence that deposited in a series of deltaic environment such as the delta-front, delta-topset, and fluvio-deltaic environments [17]. The top of the formation is marked by the first occurrence of fossiliferous marine shale bed at the base of the continental Benin Formation. The base is an expansive sandstone body that overlies Akata Shale. Interdedded shales of the Agbada Formation are possibly source rocks. However, [23] opined that Akata Formation was the main source rock of the Niger Delta. Its age ranges from Eocene to Pleistocene.

The Benin Formation (Miocene-Recent) is the youngest unit in the basin. With a minimum thickness of over $6000 \mathrm{ft}$, the formation consists mainly of sand, gravels and back-swamp deposits [24]. The shallowest part of the sequence is composed almost entirely of continental sand. The sands and sandstones are coarse-grained, sub-angular to well-rounded and are very poorly sorted. It also contains streaks/lenses of shale, clays, etc. The sands and sandstones are white or yellowish-brown because of limonitic coatings [17]. It was deposited in alluvial or upper coastal plain environments following a southward shift of deltaic deposition into a new depobelt. The formation thins towards the basin and pinches out near the shelf edge.

\section{Materials and Methods}

A total of ninety ditch cutting samples collected at $30 \mathrm{ft}$ interval from OSE-1 well offshore western Niger Delta together with the digital log data (Gamma ray log) of the well were available for the present study. All the samples were composted at $60 \mathrm{ft}$ to reduce the number of samples to 45 . The well belongs to Chevron Nigeria Limited. The interpretation of Gamma ray log obtained for the well was undertaken using Petrel software. The samples used from the present study came from the interval 6330 to $9010 \mathrm{ft}$. Samples were analyzed for their lithologic, textural and palynological contents. Precisely ten grammes $(10 \mathrm{~g})$ of each sample 
was treated according to the standard palynological preparation technique for geologic samples recommended by [25]. Samples were first treated with $10 \%$ hydrochloric acid, $\mathrm{HCl}$ to eliminate any carbonate minerals that may be present in the samples. The next procedure was not embarked upon until complete neutralization of the acid with distilled water. Thereafter the samples were treated with $35 \% \mathrm{HF}$ to remove silicate materials. The residue was again treated with $10 \% \mathrm{HCl}$ to remove any Fluorosilicate that may have formed during reaction with $\mathrm{HF}$. The palynomorphs were separated from the residue using zinc chloride, $\mathrm{ZnCl}_{2}$ (specific gravity 2.2) and centrifuged at $2000 \mathrm{rev} / \mathrm{min}$ for 5 minutes. This process helped to separate the palynoflora which was decanted and rinsed thrice with distilled water. Density separation was followed by acetolysis to dissolve cellulose for easy identification of palynomorphs. Two drops of the residue containing sporomorphs were spotted onto cover slip measuring 32 by $22 \mathrm{~mm}$ and placed on slide warmer (low-temperature hot plate) to dry. The cover slip was sealed permanently onto a glass slide (76 by $26 \mathrm{~mm}$ ) by means of petropoxyl resin.

Sporomorphs were identified and counted under high magnification National optical binocular microscope under oil immersion at Musumolu Ltd, Lagos. Sporomorphs were identified to the lowest taxonomic level possible. Identification of fossil taxa was done by comparison with published literature such as [8] and other published albums. Photomicrographs of the most vital palynomorphs were taken at $\times 100$ oil immersion objective. Palynomorphs were classified into five groups based on ecological and morphological affinities with modern taxa namely, pollen, spores, marine, fungi spore, and freshwater algae. Marine group made up of dinoflagellates, foraminifera inner linings and archritarch were also documented.

Chronostratigraphic inferences were deduced based on traditional graphic correlation method which is premised on the relative abundances, first appearance datum (FAD) and Last appearance datum (LAD) of the fossil palynomorphs present in the stratigraphic section to erect palynological zonations [8]. The biozonation of OSE-1 well is based on palynological zonation schemes of [9] and [8] for the Niger Delta stratigraphic successions.

\section{Results}

All the samples analyzed were fine-grained, brownish gray to light gray shales with a few gypsiferous samples from the lower portion of the well. The studied stratigraphic interval of OSE - 1 well yielded low to high diversity assemblages of palynomorphs. The total assemblages consisted of 29 pollen taxa, 17 dinoflagellates, 9 pteridophitic fern spores, one freshwater algae and one acritarch, excluding unidentifiable forms. A total of 574 counts of palynomorphs were recorded in 45 slides (samples). The recouped palynomorphs comprised 251 pollen grains (43.73\%), 230 spores (40.07\%), 58 dinoflagellate cysts (10.11\%), 34 algal spores $(5.92 \%)$ and one fungal spore $(0.20 \%)$ (Figure 2$)$. The palynomorph assemblages 


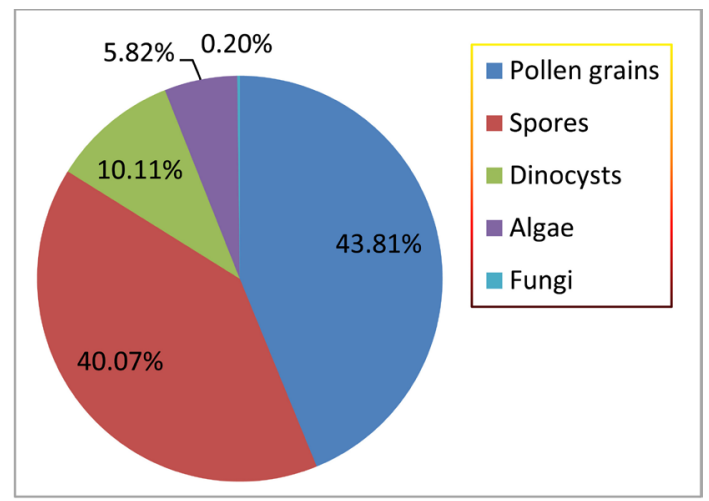

Figure 2. Pie chart showing the percentage frequency distribution of different palynomorph groups retrieved from OSE 1 well.

were moderately well preserved. The stratigraphic distribution of the palynoflora was highly variable. Some palynomorphs were common (e.g Monoporites annulatus and Laevigatosporites sp) while others (e.g Foveotriletes margaritae and Belskipollis elegans) had rare occurrence. Pollen grains accounted for the highest counts, followed by spores, dinocysts, algae acritarch and fungi element which had a single count. The assemblage distribution chart and photomicrographs of some important taxa are shown in Figure 3 and Plate 1.

The pollen grains recouped from the studied interval of OSE 1 well were $M o$ noporites annulatus, Zonocostites ramonae, Pollen indeterminate, Sapotaceoidaepollenites sp., Psilatricolpites sp., Psilatricolporites sp., Monocolpites sp., Striatopollis calatumbus, Inaperturopollenites sp., Verrutricolporites sp., Pachydermites diederixi, Retitricolporites irregularis, Gemmamonoporites sp. Psilatriporites sp., Racemonocolpites hians, Retibrevitricolporites obadoensis, Canthiumidites sp., Nymphaepollis sp., Praedapollis flexibilis, Proteacidites cooksonni, Psilatricolpites sp., Retistephanocolpites gracilis, Verrutricolporites rotundiporus, Belskipollis elegens, Echiperiporites estalae, Peregnipollis nigericus, Proxapertites cursus, Proxapertites operculatus, Retistephanocolpites sp. and Retitricolporites sp. listed in order of decreasing abundance. Of these, Monoporites annulatus and Zonocostites ramonae, Pollen indeterminate, Psilatricolpites $s p$., Psilatricolporites sp. dominated the assemblage, accounting for more than half of the pollen counts. Pollen grains showed consistent occurrence from the lowest depth $(8980-9010 \mathrm{ft})$ to the highest studied stratigraphic level at $6330-6360 \mathrm{ft}$, only absent at 7960 - $7990 \mathrm{ft}$ horizon. The highest frequency of pollen grains (44) was recorded at 7420 - $7450 \mathrm{ft}$ level and also coincided with the highest pollen diversity (8). Other minor peaks occurred at 6930 - $6960 \mathrm{ft}$ and $6330-6360 \mathrm{ft}$. Both pollen frequencies and diversity appeared to show an upward increasing trend in a repetitive cyclic pattern (Table 1). Other minor peaks occurred at $6930-6960$ $\mathrm{ft}$ and 6330 - $6360 \mathrm{ft}$. The array of pollen was dominated by angiosperm pollen. The assemblage of spores (nine identified taxa) was predominantly pteridophytic spores and a single record of fugal spore. They were Laevigatosporites sp., Acrostichum aureum, Verrucatosporites sp., Polypodiaceoisporites sp., Stereisporites 


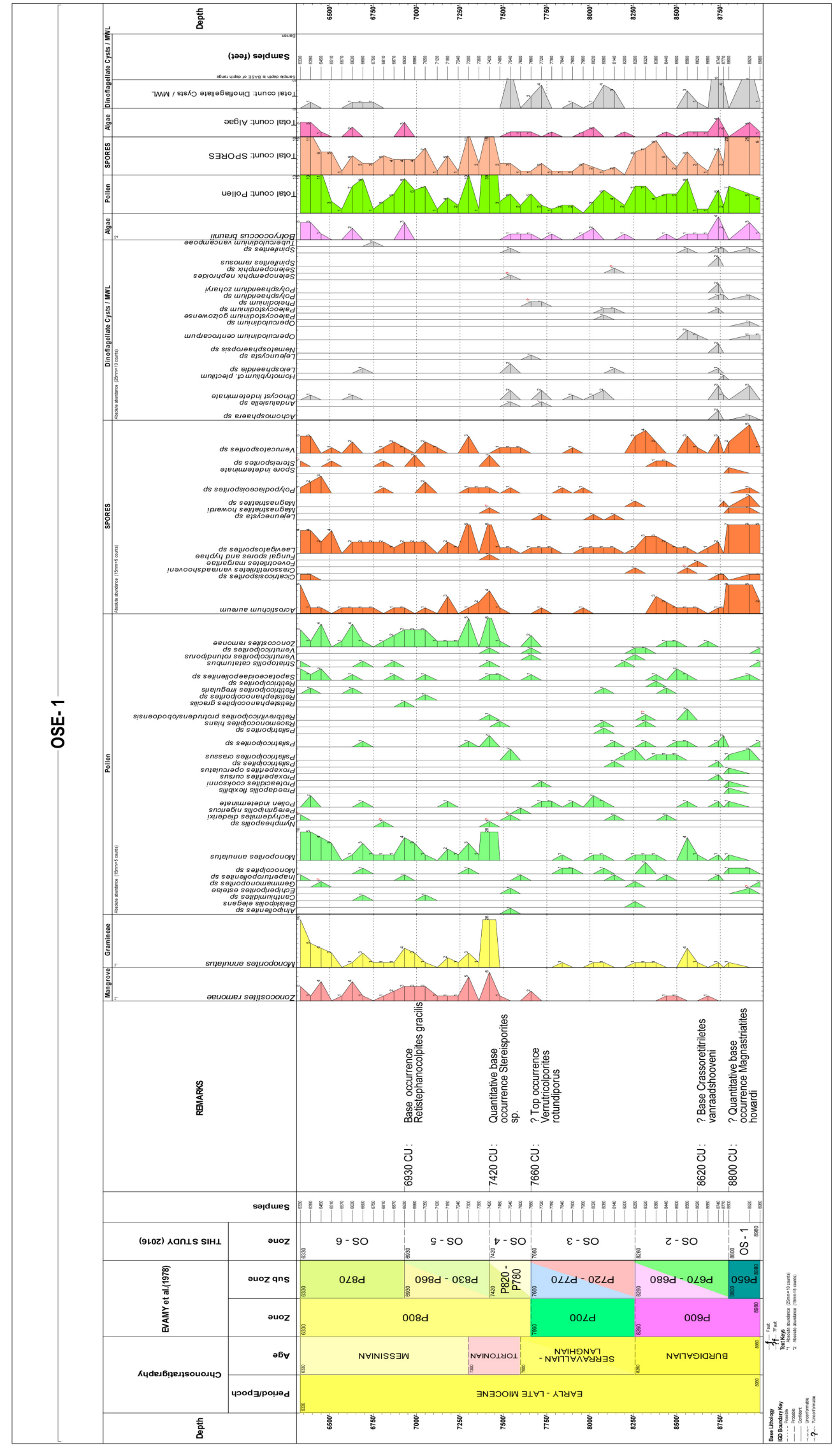




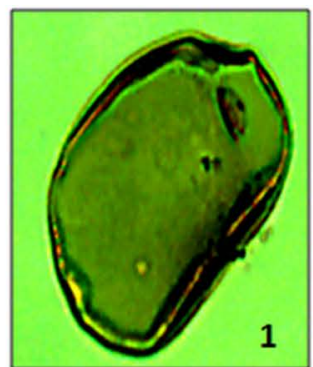

1. Laevigatosporites sp.

$\times \mathbf{4 0 0}$

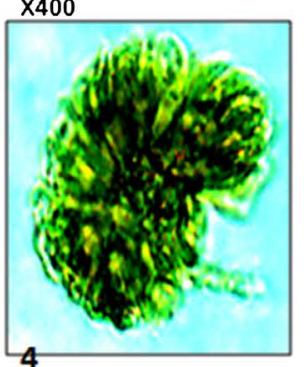

4. Botryococcus braunii. $5170 \mathrm{ft}$. $\times 400$

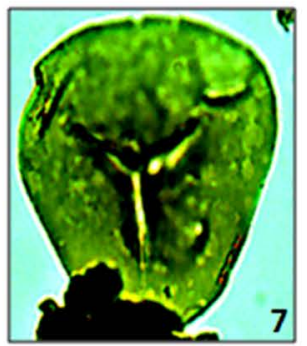

7. Acrostichum aureum. $\times 400$

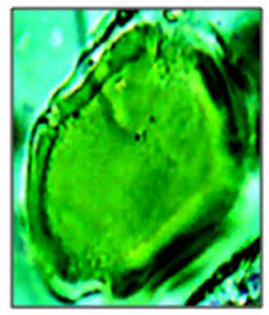

10. Pachydermites diederixi. . X400

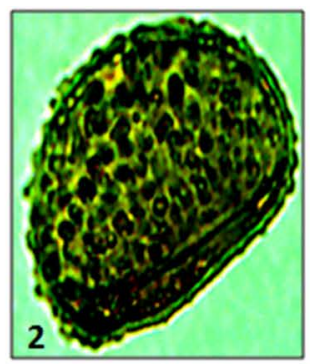

2. Verrucatosporites $\mathrm{sp}$.

$\times 400$

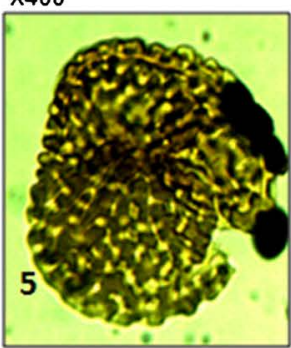

5. Crassoretitriletes vanraadshooveni. $\mathrm{X} 40 \mathrm{Z}$

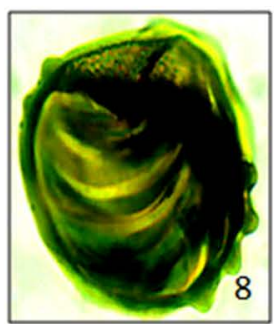

8 Maanastriatites howardi. $\times 400$

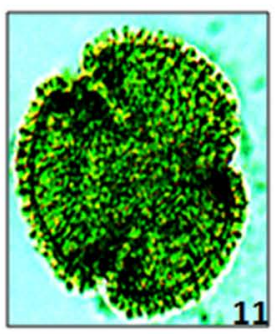

11. Retitricolporites irregularis. $\times 400$

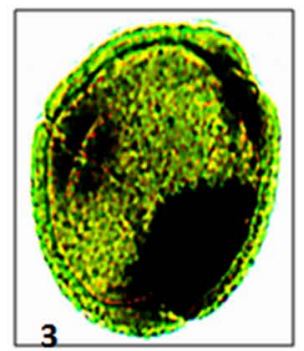

3. Psilatricolporites crassus $\mathrm{X} 400$

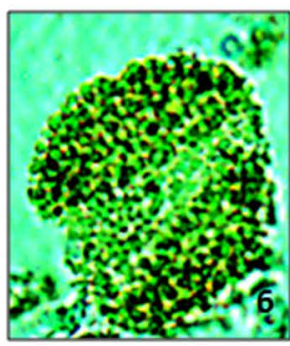

6. Racemonocolpites hians. $\mathrm{X} 400$
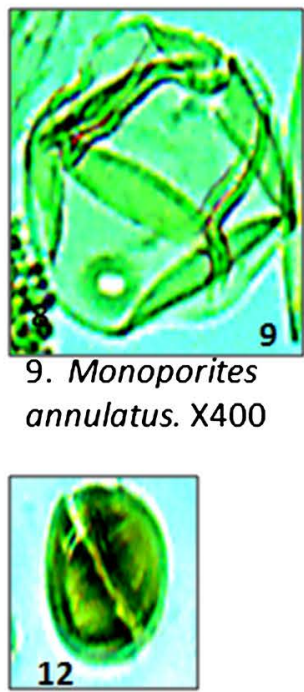

Znocostites ramonae. X400

Plate 1. Photomicrographs of some of the palynomorphs retrieved from OSE 1 well. Mag: $400 \times$.

sp., Magnastriatites howardi, Magnastriatites sp., Crassoretitriletes vanraadshooveni, Foveotriletes margaritae and Spore indeterminate, listed in order of decreasing abundance. The assemblage was dominated by Laevigatosporites sp. (39.13\%), Acrostichum aureum (23.04\%) and Verrucatosporites sp. (20.00\%). Of these three Laevigatosporites sp. showed the most consistent occurrence within the studied stratigraphic interval, missing only in a few horizons. Generally, spores occurred nearly throughout the section except for their absence at 8200 - 
Table 1. Abundance and diversity of palynomorph groups recorded in OSE 1 well.

\begin{tabular}{|c|c|c|c|c|c|c|c|}
\hline Depth & $\begin{array}{l}\text { Pollen } \\
\text { (div) }\end{array}$ & $\begin{array}{c}\text { Pollen } \\
\text { (freq) }\end{array}$ & $\begin{array}{l}\text { Spore } \\
\text { (Div.) }\end{array}$ & $\begin{array}{l}\text { Spore } \\
\text { (Freq) }\end{array}$ & $\begin{array}{c}\text { Dinocysts } \\
\text { (div) }\end{array}$ & $\begin{array}{l}\text { Dinocysts } \\
\text { (freq) }\end{array}$ & $\begin{array}{l}\text { B. braunii } \\
\text { (Freq) }\end{array}$ \\
\hline $6330-6360$ & 6 & 18 & 5 & 16 & 0 & 0 & 3 \\
\hline $6390-6420$ & 5 & 10 & 4 & 10 & 1 & 1 & 3 \\
\hline $6450-6480$ & 4 & 11 & 3 & 6 & 0 & 0 & 1 \\
\hline $6510-6540$ & 1 & 3 & 3 & 7 & 0 & 0 & 0 \\
\hline $6570-6600$ & 1 & 1 & 1 & 1 & 0 & 0 & 0 \\
\hline $6630-6660$ & 4 & 7 & 3 & 5 & 1 & 1 & 2 \\
\hline $6690-6720$ & 7 & 9 & 2 & 3 & 0 & 0 & 0 \\
\hline $6750-6780$ & 1 & 1 & 2 & 3 & 1 & 1 & 0 \\
\hline $6810-6840$ & 3 & 3 & 4 & 4 & 0 & 0 & 0 \\
\hline $6870-6900$ & 4 & 5 & 3 & 5 & 0 & 0 & 0 \\
\hline $6930-6960$ & 5 & 10 & 3 & 4 & 0 & 0 & 3 \\
\hline $6990-7020$ & 2 & 6 & 2 & 4 & 1 & 1 & 0 \\
\hline $7050-7080$ & 6 & 8 & 4 & 7 & 0 & 0 & 0 \\
\hline $7120-7150$ & 1 & 1 & 1 & 1 & 0 & 0 & 0 \\
\hline $7180-7210$ & 3 & 4 & 2 & 5 & 0 & 0 & 0 \\
\hline $7240-7270$ & 2 & 2 & 1 & 1 & 0 & 0 & 0 \\
\hline $7300-7330$ & 3 & 7 & 4 & 11 & 0 & 0 & 0 \\
\hline $7360-7390$ & 2 & 2 & 2 & 3 & 0 & 0 & 0 \\
\hline $7420-7450$ & 8 & 44 & 6 & 15 & 0 & 0 & 0 \\
\hline $7480-7510$ & 4 & 4 & 3 & 3 & 0 & 0 & 0 \\
\hline $7540-7570$ & 3 & 4 & 2 & 2 & 5 & 6 & 1 \\
\hline $7600-7630$ & 2 & 2 & 1 & 1 & 0 & 0 & 1 \\
\hline $7660-7690$ & 4 & 5 & 1 & 1 & 2 & 2 & 1 \\
\hline $7720-7750$ & 2 & 2 & 2 & 2 & 3 & 4 & 0 \\
\hline $7780-7810$ & 1 & 1 & 1 & 1 & 0 & 0 & 1 \\
\hline $7840-7870$ & 2 & 2 & 1 & 1 & 0 & 0 & 0 \\
\hline $7900-7930$ & 2 & 2 & 1 & 1 & 1 & 1 & 0 \\
\hline 7960 - 7990 & 0 & 0 & 3 & 3 & 0 & 0 & 1 \\
\hline $8020-8050$ & 2 & 2 & 1 & 1 & 2 & 2 & 2 \\
\hline $8080-8110$ & 6 & 6 & 1 & 1 & 3 & 4 & 0 \\
\hline $8140-8170$ & 5 & 5 & 1 & 1 & 4 & 4 & 0 \\
\hline $8200-8230$ & 2 & 2 & 0 & 0 & 0 & 0 & 1 \\
\hline $8260-8290$ & 6 & 7 & 4 & 6 & 0 & 0 & 0 \\
\hline $8320-8350$ & 5 & 6 & 2 & 7 & 0 & 0 & 0 \\
\hline $8380-8410$ & 4 & 4 & 4 & 9 & 0 & 0 & 0 \\
\hline
\end{tabular}




\begin{tabular}{cccccccc} 
Continued & & & & & & & \\
\hline $8440-8470$ & 5 & 5 & 3 & 5 & 0 & 0 & 1 \\
$8500-8530$ & 5 & 5 & 2 & 2 & 0 & 0 & 0 \\
$8560-8590$ & 4 & 7 & 3 & 5 & 2 & 3 & 1 \\
$8620-8650$ & 1 & 1 & 3 & 3 & 1 & 1 & 1 \\
$8680-8710$ & 1 & 1 & 1 & 1 & 0 & 0 & 1 \\
$8740-8770$ & 6 & 6 & 3 & 6 & 9 & 14 & 4 \\
$8770-8800$ & 1 & 2 & 3 & 3 & 4 & 4 & 2 \\
$8800-8890$ & 7 & 7 & 5 & 21 & 0 & 0 & 0 \\
$8920-8950$ & 4 & 7 & 6 & 26 & 6 & 8 & 3 \\
$8980-9010$ & 4 & 4 & 3 & 8 & 1 & 1 & 1 \\
Total & & 251 & & 231 & & 58 & 34 \\
\hline
\end{tabular}

$8230 \mathrm{ft}$ depth. The maximum assemblage diversity (6) were recorded at 8800 $8890 \mathrm{ft}$ and $7420-7450 \mathrm{ft}$, with former also corresponding to the peak abundance of 26 counts (see Figure 2 and Table 2). Fresh water algae were represented by a single taxon, Botryococcus braunii. Its occurrence, though sporadic in some parts of the stratigraphic interval, was quite significant with 34 counts out of a total sum of 574 .

The recorded dinocyts were Lejeunecysta sp., Operculodinium centrocarpum, Spiniferites sp., Achomosphaera sp., Leiosphaeridia sp., Paleocystodinium sp., Polysphaeridium sp., Andalusiella sp., Nematosphaeropsis sp., Polysphaeridium zoharyi, Spiniferites ramosus, Homotryblium plectilum, Operculodinium sp., Paleocystodinium golzowense, Phelodinium sp., Selenopemphix nephroides, Selenopemphix $s p$. and Tuberculodinium vancampoae, listed in order of decreasing abundance. Dinocyst indeterminate recorded the highest frequency. Dinoflagellate cysts or dinocysts retrieved from the well attained maximum assemblage diversity of 9 and maximum abundance of 14 at $8740-8770 \mathrm{ft}$. Their occurrence was mainly confined to two stratigraphic intervals, $9010-8560 \mathrm{ft}$ and $8170-7540 \mathrm{ft}$, with only three counts occurring outside these horizons and towards the top of the studied interval of the well. Overall, the pollen and spore abundances were roughly equal even the pollen record was quite more diverse (Table 1).

\section{Phytoecological Characterization}

Following [26], the total palynomorphs assemblages were categorized into five phytoecological classes since majority of the microfloras could be linked to extant plant families (see Table 2). The comparison was based on both morphological similarity and ecological affinities with modern plant relatives. The botanical affinity of some palynomorphs could, however, not be ascertained. The fossil pollen Peregrinipollis nigericus, a tricolpate, was considered to have unknown botanical affinities even though the pollen was morphologically similar 
Table 2. Botanical affinities of some of the recouped pollen/spores and the ecological preferences of extant parent plants.

\begin{tabular}{|c|c|c|}
\hline Species/Taxon & Botanical affinity & Ecology \\
\hline Crassoretitriletes & Lygodium microphyllum [8] & Swampy \\
\hline \multicolumn{3}{|l|}{ vanraadshooveni } \\
\hline Echiperiporites estelae & Malvaceae [8] & Coastal vegetation/fluvial \\
\hline Magnastriatites howardi & Parkeriaceae, Ceratopsis [8] & Freshwater fern [8] \\
\hline Monoporites annulatus & Poaceae $[8]$ & $\begin{array}{l}\text { Open vegetation in the tropics; } \\
\text { river valley in dry climatic settings }\end{array}$ \\
\hline Pachydermites diederixi & Symphonia globulifera [8] [31] & Mangrove [30] \\
\hline Striatopollis catatumbus & Fabaceae/Crudia [8] & $\begin{array}{l}\text { Alluvial broad leaved evergreen } \\
\text { temperate trees, [32] }\end{array}$ \\
\hline Retitricolporites irregularis & Amanoa $[8]$ & $\begin{array}{l}\text { Lowland forest Germeraad et al., } \\
\text { 1968; }\end{array}$ \\
\hline Zoncostites ramonae & Rhizophoraceae Rhizophora sp. [8] & Mangrove \\
\hline
\end{tabular}

to that of modern genus Brachystegia [27]. The identified phytoecological groups were mangrove elements, freshwater swamp and water edge elements, rain forest elements, savannah elements represented mainly by Gramineae pollen, Monoporites annulatus, as well as marine elements represented by dinoflagellate cysts. Other groups were freshwater algae represented by Botryococcus braunii and fungal spore (see Table 3) The identified mangrove elements were represented by Acrostichum aureum, Zonocostites ramonae, Psilatricolporites crassus, Pachydemites diederixi, Proxapertites cursus and Verrutricolporites sp. Of these, the first two were the most dominant, accounting over $65 \%$ of the total mangrove elements, The freshwater swamp and water edge elements were characterized by Laevigatosporites sp., Retitricolporites irregularis and Striatopollis catatumbus, with Laevigatosporites accounting for more than half of the group frequency. The marine element comprised a wide spectrum of dinoflagellate cysts already listed in this work. They included Spiniferites sp. and Polysphaeridium zoharyi with a good representation of both Peridnioids (e.g. Lejeunecysta $s p$. and Paleocystodinium) and Gonyalacoids (e.g. Polysphaeridium zoharyi and Tuberculodinium vancamporae) genera. Savannah element was restricted to the occurrence of a single taxon Monoporites annulatus, a well known Gramineae (Poaceae) or grass pollen. Its distribution in the studied stratigraphic interval was more consistent in the upper half of the well interval, from $720-6330 \mathrm{ft}$. The coastal plain elements were presented by Magnastriatites howardi, Crassorettriletes vanraadshooneni, Echiperiporites estalae, and Retitricolporites sp. while the rain forest elements were Polypodiaceoisporites sp., Sapotaceoidaepollenites sp., Canthiumidites sp. and Nymphaepollis sp.

[28] reported the abundant presence of Zonocostites ramonae in the mangrove communities of Venezuela with a wide geographic spread in the Early Miocene. $Z$. ramonae is traceable to the fossil pollen of Rhizophora, the predominant genus in 
Table 3. Phytoecological groups from OSE 1 well, Niger Delta.

\begin{tabular}{|c|c|c|c|c|c|c|c|}
\hline $\mathrm{S} / \mathrm{N}$ & Depth (ft) & Marine & Mangrove & Freshwater & Coastal plain & Rain forest & Savannah \\
\hline 1 & $6330-6360$ & 0 & 9 & 5 & 0 & 5 & 10 \\
\hline 2 & $6390-6420$ & 1 & 2 & 5 & 0 & 3 & 5 \\
\hline 3 & $6450-6480$ & 0 & 5 & 2 & 0 & 5 & 4 \\
\hline 4 & $6510-6540$ & 0 & 0 & 4 & 0 & 0 & 3 \\
\hline 5 & $6570-6600$ & 0 & 2 & 0 & 0 & 0 & 0 \\
\hline 6 & $6630-6660$ & 1 & 5 & 3 & 0 & 1 & 1 \\
\hline 7 & $6690-6720$ & 0 & 2 & 3 & 0 & 1 & 3 \\
\hline 8 & $6750-6780$ & 1 & 1 & 2 & 0 & 0 & 1 \\
\hline 9 & $6810-6840$ & 0 & 1 & 1 & 0 & 2 & 1 \\
\hline 10 & $6870-6900$ & 0 & 3 & 3 & 0 & 1 & 1 \\
\hline 11 & $6930-6960$ & 0 & 4 & 2 & 0 & 0 & 4 \\
\hline 12 & $6990-7020$ & 1 & 3 & 2 & 0 & 0 & 3 \\
\hline 13 & $7050-7080$ & 0 & 4 & 2 & 0 & 4 & 1 \\
\hline 14 & $7120-7150$ & 0 & 1 & 0 & 0 & 0 & 0 \\
\hline 15 & $7180-7210$ & 0 & 4 & 2 & 0 & 0 & 2 \\
\hline 16 & $7240-7270$ & 0 & 1 & 1 & 0 & 0 & 1 \\
\hline 17 & $7300-7330$ & 0 & 6 & 6 & 0 & 1 & 0 \\
\hline 18 & $7360-7390$ & 0 & 2 & 0 & 0 & 1 & 1 \\
\hline 19 & $7420-7450$ & 0 & 6 & 7 & 1 & 3 & 36 \\
\hline 20 & $7480-7510$ & 0 & 3 & 1 & 0 & 1 & 0 \\
\hline 21 & $7540-7570$ & 6 & 3 & 1 & 1 & 1 & 0 \\
\hline 22 & $7600-7630$ & 0 & 0 & 0 & 0 & 0 & 0 \\
\hline 23 & $7660-7690$ & 2 & 3 & 1 & 0 & 1 & 0 \\
\hline 24 & $7720-7750$ & 4 & 1 & 1 & 0 & 0 & 0 \\
\hline 25 & $7780-7810$ & 0 & 0 & 1 & 0 & 0 & 0 \\
\hline 26 & $7840-7870$ & 0 & 0 & 0 & 0 & 1 & 1 \\
\hline 27 & $7900-7930$ & 1 & 0 & 0 & 0 & 0 & 0 \\
\hline 28 & $7960-7990$ & 0 & 1 & 1 & 0 & 1 & 0 \\
\hline 29 & $8020-8050$ & 2 & 0 & 1 & 0 & 0 & 1 \\
\hline 30 & $8080-8110$ & 4 & 0 & 2 & 0 & 0 & 1 \\
\hline 31 & $8140-8170$ & 4 & 1 & 1 & 0 & 0 & 0 \\
\hline 32 & $8200-8230$ & 0 & 1 & 1 & 0 & 0 & 0 \\
\hline 33 & $8260-8290$ & 0 & 3 & 1 & 1 & 0 & 1 \\
\hline 34 & $8320-8350$ & 0 & 0 & 3 & 0 & 0 & 1 \\
\hline 35 & $8380-8410$ & 0 & 4 & 3 & 1 & 1 & 1 \\
\hline 36 & $8440-8470$ & 0 & 5 & 3 & 0 & 0 & 0 \\
\hline
\end{tabular}




\begin{tabular}{|c|c|c|c|c|c|c|c|}
\hline \multicolumn{8}{|c|}{ Continued } \\
\hline 37 & $8500-8530$ & 0 & 3 & 1 & 0 & 1 & 0 \\
\hline 38 & $8560-8590$ & 3 & 0 & 1 & 1 & 0 & 4 \\
\hline 39 & $8620-8650$ & 1 & 1 & 0 & 0 & 0 & 1 \\
\hline 40 & $8680-8710$ & 0 & 1 & 1 & 0 & 0 & 0 \\
\hline 41 & $8740-8770$ & 14 & 2 & 2 & 0 & 0 & 1 \\
\hline 42 & $8770-8800$ & 4 & 1 & 0 & 1 & 0 & 0 \\
\hline 43 & $8800-8890$ & 0 & 10 & 7 & 2 & 0 & 1 \\
\hline 44 & $8920-8950$ & 8 & 9 & 11 & 1 & 2 & 2 \\
\hline 45 & $8980-9010$ & 1 & 3 & 6 & 0 & 0 & 0 \\
\hline
\end{tabular}

modern day Neotropical mangrove communities. Fossil evidence revealed that the pollen grain made its first appearance in Late Eocene in low frequencies, and became dominant in lower coastal mangrove communities starting from the Miocene to the present[14] [28], working with sediments from Tertiary Niger Delta noted close morphological similarities between the genus Acrostichumsporites and the pollen Acrostichum aureum which was observed to be the main pteridophyte thriving within the present day mangrove niche. They further posited, referencing [29] that Acrostichum was adapted to mangrove vegetation, especially areas prone to frequent saline water inundation, including open salt marshes, estuaries and coastal swamps.

\section{Discussion}

\subsection{Chronostratigraphy}

Palynomorphs, because of their abundant occurrence in wide spectrum of facies and rapid evolutionary changes are veritable tool for biostratigraphic and peleoecological studies (Traverse, 2007). Palynological chronostratigraphic zones were erected dependent on the identification of some key parameters of fossil palynotaxa like first appearance datum (FAD), last appearance datum (LAD), peak development and their absence. Some stratigraphic marker palynomorphs such as Crassoretitriletes vanraadshooveni, Racemonocolpies hians and Verrutricolporites rotundiporus retrieved from the well section facilitated zonation. The studied interval from 6330 to $9010 \mathrm{ft}$ was subdivided into six informal zones namely OS-1 to OS-6. The zones corresponded to P600 - P800 t0 of [9]. The recognized zones were as discussed below.

\section{ZONE OS-I.}

SUBZONE: P650.

INTERVAL: 9010 - $8800 \mathrm{ft}$.

AGE: Early Miocene.

DIAGNOSIS: This is the first and oldest zone in the studied section of OSE -1 well. The top of zone OS-1 is marked by the quantitative base of occurrence of Magnastriatites howardi at 8800 - $8890 \mathrm{ft}$. The age of the zone is early Burgida- 
lian of Early Miocene which is correlated to the P650 subzone of [9]. The highest occurrences were seen for Acrostichum aureum and Laevigatosporites sp. Peak occurrence of spores was recorded within this zone. The base of the zone was not encountered in the well as it lay below the maximum investigated depth. In addition, the zone was characterized by Early Miocene marker Verrutricolporites rotundiporus which had its FAD coinciding with the base of Miocene and was abundant in the Early Miocene in Nigeria but disappeared from the stratigraphic record in the middle Miocene [8]. The base of $V$. rotundiporus could not be established because of its spotty occurrence.

ZONE: OS-2.

SUBZONE: P670-P680.

INTERVAL: $8800-8260 \mathrm{ft}$.

AGE: Early Miocene.

DIAGNOSIS: The top of zone OS-2 was identified by the base or first appearance datum (FAD) of Crassoretitriletes vanraadshooveni which is the base of zone OS-3. The base of the zone is delineated by the quantitative first appearance datum of Magnastriatites howardi at 8800 - $8890 \mathrm{ft}$. The age of the zone is Burdigalian of Early Miocene and is equivalent to the subzone P670 - P680 of Evamy et al. (1978). The zone is characterized by the Peak occurrence and maximum diversity assemblage of marine elements dinoflagellates cysts, including Achomosphaera sp., Paleocystodinium sp., Homotryblium plectilum and Nematosphaeropsis sp. at 8740 - $8770 \mathrm{ft}$. Also, the zone was characterized by low occurrence of Monoporites annulatus. Other pollen occurring within the zone included Verrutricolporites rotundiporus, Psilatricolporites crasus and Psilatricolporites sp. [33] reported that the FAD of the Homotryblium plectilum was contained within the Late Early - Late Miocene strata.

ZONE: OS-3.

SUBZONE: P720-P770.

INTERVAL: 8260-7660 ft.

AGE: Early Middle Miocene.

DIAGNOSIS: The top of zone OS-3 was marked by the last appearance datum (LAD) of Verrutricolporites rotundiporus at 7660 - $7690 \mathrm{ft}$ while the base was defined by first appearance datum (FAD) of Crassoretitriletes vanraadshooveni and corresponded to the top of OS-2 subzone. The age of the zone is Langhian Serravilian of Early Miocene to Middle Miocene and is equivalent to the subzones P720 - P770 of [9]. The zone is characterized by low occurrence of Zonocostities ramonae, Pollen indeterminate, Proxapertites cursus, Psilatricolporites crassus, Psilatricolporites $s p$, Retitricolporites irregularis, Retitricolporites $s p$, Retitriporites sp, Striamonocolpites rectostriatus, Striatricolpites undulatus, and Verrucatosporites usmensis. Monocolpites sp and Monoporites annulatus

ZONE: OS-4

SUBZONE: P780 - P820.

INTERVAL: 7660 - $7420 \mathrm{ft}$. 
AGE: Middle Miocene.

DIAGNOSIS: The top of zone OS-4 was marked by the quantitative base occurrence of stereisporites sp. at 7420 - $7450 \mathrm{ft}$ and the base was defined by the LAD of Verrutricolporites rotundiporus at 7660 - $7690 \mathrm{ft}$. The age of the zone is Latest Serravilian-Tortonian of Middle Miocene and is equivalent to P780 P820 of [9]. Other features of this zone included abundant presence of $M$. annulatus and absence of Verrutricolporites rotundiporus and Magnatriatites howardi. This zone probably straddled the Middle/Late Miocene since the divide is placed at the P780/P820. The presence of Striatopollis catatumbus confirmed the middle Miocene age for the interval. [33] stated that the top consistent occurrence of Racemonocolpites hians marked the boundary between Middle and Late Miocene (P780/P820) in the Niger Delta. This boundary could not be placed with confidence in the present study because of the sporadic occurrence of $R$. hians. Therefore the two subzones were merged.

ZONE: OS-5.

SUBZONE: P830 - P860.

INTERVAL: 7420 - $6930 \mathrm{ft}$.

AGE: Middle Miocene - Late Miocene.

DIAGNOSIS: The top of zone OS-5 was marked by the base occurrence of Retistephanocolporites gracilis at 6930 - $6960 \mathrm{ft}$ and the base was marked by the quantitative base occurrence of stereisporites sp. at $7420-7450 \mathrm{ft}$. The age of the zone is Tortonian-Messinian of Middle/Late Miocene and was equivalent to P830 - P860 of [9].

ZONE: OS-6.

SUBZONE: 870 .

INTERVAL: 6930 - $6330 \mathrm{ft}$.

AGE: Late Miocene.

DIAGNOSIS: The top of zone OS-6 was situated stratigraphically above the youngest studied sediment in the well. This was the youngest studied interval. Its base was marked by the base occurrence of Retistephanocolporites gracilis at 6930 - $6960 \mathrm{ft}$. The age of the zone was Messinian of Late Miocene and was equivalent to P870 zone of [9]. The zone was characterized by abundant occurrence of $M$. annulatus and $Z$. ramonae. Other forms present in the zone included Laevigatosporites sp., Acrostichum aureum and Sapotaceoidaepollenites sp. The top of the zone was stratigraphically higher than the start depth of $6330 \mathrm{ft}$.

\subsection{Paleoclimate}

The understanding of the ecology of the parent plants of fossil palynomorphs was deployed to aid identification of temporal variations in ecology and climate. Environment of deposition and climate exert primary controls on lithofacies (e.g sandstone or shale) and well as on the composition and diversity of palynofloras. As for example, the presence of marine elements such as Dinoflagellate cysts may indicate deposition in coastal environment like nearshore, brackish lagoon, 
open salt marshes while its absence implied deposition on continental settings. The vegetation of any province was determined largely by the geology of the area (soil and parent rocks) and climate [30]. Therefore climate exerts primary control on vegetation. One of the major goals of paleoenvironmental reconstruction is to simulate a virtual picture of past vegetation using fossil evidence such as microfloristic components of rocks. Temporal variations in climate, a key environmental factor, usually manifest as changes in vegetation, including evolution of new taxa or extinction. [10] employed the knowledge of pollen-parent plantecology as a means of identifying changes in vegetation through time (biosignals) presumably resulting from paleoclimatic changes as fine scale correlation tool in the Late Miocene EA field of Niger delta to subdivide existing biozone into smaller, reservoir scale time slices. Environmental changes are usually reflected in the palynological assemblages [13].

Many authors including [8] [30] [5] as well as [19] have used the relative abundance of Gramineae or Poaceae (grass Pollen) typified by Monoporites annulatus and Rhizophora (mangrove pollen) typified by Zonocostites ramonae to make deductions on paleoclimate. Another paleoclimate proxy frequently used in conjunction with the Gramiineae/Rhizophora ratio was knowledge of the ecological preferences of the fossil pollen parent plants, e.g. [10] and [30]. The phytoecological categorization of some of the forms encountered in this study is shown in Figure 4 and Table 2. It can be observed from the palynological distribution chart (Figure 3 ) that there was scanty and sporadic record of both Monoporites annulatus and $Z$. ramonae with the former indicating higher occurrence from the deepest level of the well $(8980-9010 \mathrm{ft})$ to $7480-7510 \mathrm{ft}$. This probably indicated warmer/dryer period because of the dominance of grass pollen over mangrove pollen. This might also suggest deposition in continental setting. Periods of sea level fall were often associated with minimal development of mangrove vegetation [4] [34]. It has been emphasized by [32], referencing [8], that increased occurrence of Gramineae pollen (represented by $M$. annulatus) indicated prevalence of open vegetation and development of extensive grass land in a generally dry climate with marked rainy seasons. Further evidence corroborating this inference was the presence of Polysphaeridium zoharyi within the interval. The dinocyst $P$. zoharyi is adapted to high salinity waters. [33] posited that Polysphaeridium zoharyi was a taxon adapted to very saline waters and therefore indicative of arid or dry climate. The freshwater fern, Laevigatosporites $s p$. despite having a good representation in the interval, was intermittent in its occurrence, indicating that freshwater bodies frequently dried up because of extended dry climatic conditions. The record of Botryococcus braunii in this zone was high which might suggest frequent to intermittent influx of freshwater. The algae however had been known to be adapted to even saline brackish water so that its occurrence did not necessarily indicate persistent freshwater influx into depositional site [35]. The percentage pollen recorded for the interval appeared cyclical, falling from $78 \%$ at $8920-8950 \mathrm{ft}$ to $00.00 \%$ at $8200-8230 \mathrm{ft}$ and peak- 
ing again to $100.0 \%$ at $7960-7990 \mathrm{ft}$ (Appendix 1). The pattern was consistent with climate switching between dryer and wetter phases.

The upper half of the well, the interval $7420-7450 \mathrm{ft}$ to the highest level 6330 - $6360 \mathrm{ft}$ was marked by increased occurrences of both Monoporites annulatus and $Z$. ramonae (Figure 4). The interval was also characterized by higher frequencies and diversities of pteridophytic spores. This observation implied the persistent presence of expanded mangrove communities during the interval. There was higher and more consistent occurrence of freshwater and water edge elements, especially Laevigatosporites sp. (Figure 3). The percentage spores or pollen/spore ratio did not vary much (Appendix 1). This interval probably

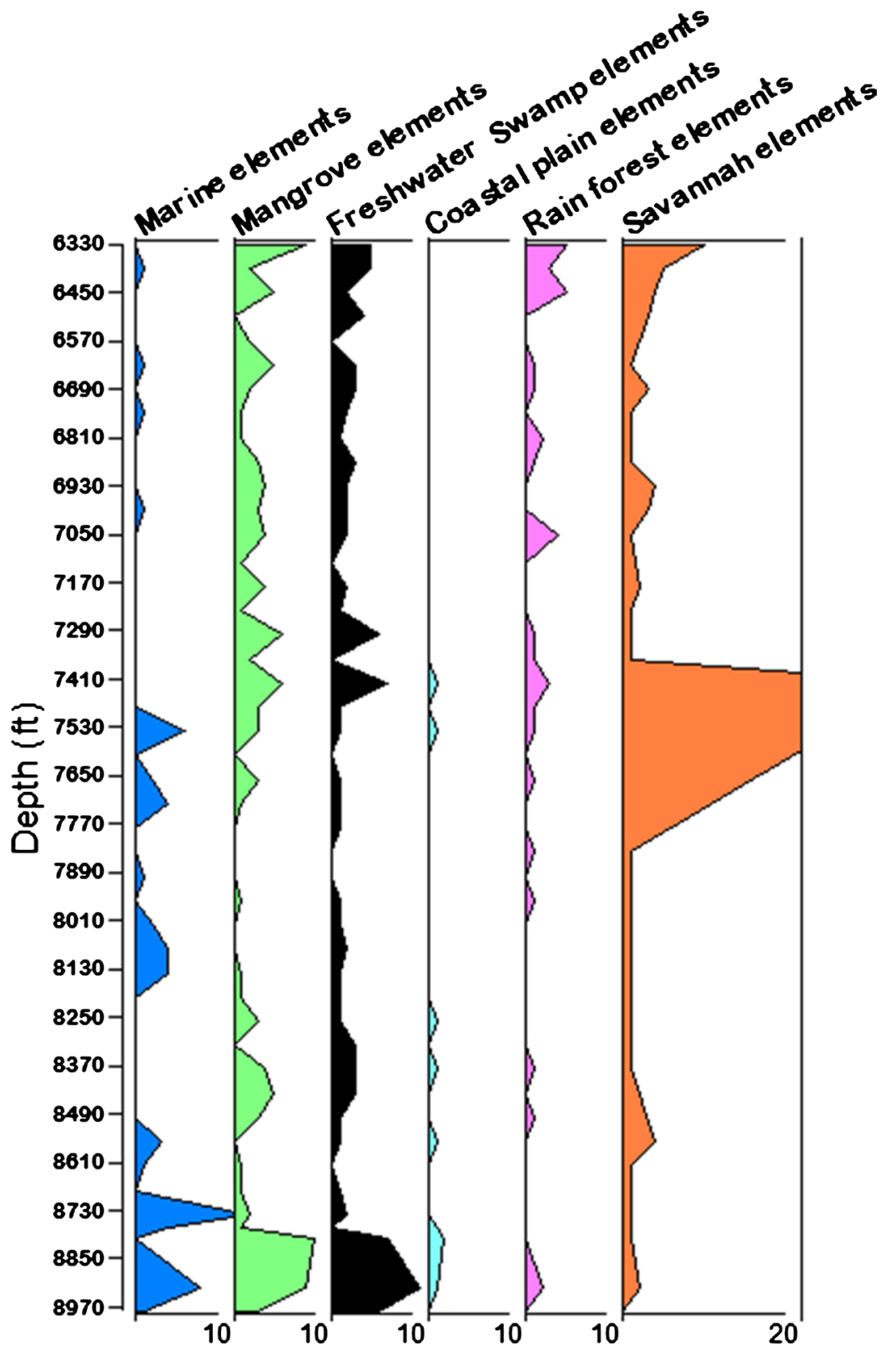

Figure 4. Stratigraphic distribution of various phytoecological groups of palynofloras from OSE 1 well. 
indicated the return of wetter tropical climate. Most pteridophytic ferns are adapted to warm and humid tropical climate [26]. This deduction was corroborated by [33] who posited while referencing [36] that abundant records of the mangrove pollen species Zonocostites ramonae occurring in association with abundant freshwater swamp, brackish water swamp, aracaceous pollen alongside freshwater algae was indicative of wet and cold climate.

\subsection{Depositional Paleoenvironment}

The depositional environment was interpreted by considering the ecological affinities of fossil pollen parent plants, variations in the proportions of terrestrial and marine elements in conjunction with the presence or absence of marine elements in the assemblages. On this basis, the stratigraphic interval under consideration was divided into four depositional zones, namely zones I to IV (Figure 3, Table 1). Zone I occupied the lowest portion of the well in the interval $9010 \mathrm{ft}$ to $8560 \mathrm{ft}$. The interval was characterized by abundant records of marine elements (dinoflagellate cysts) of high diversity assemblage (highest diversity of 9). The sediment in this zone was probably deposited in coastal marine settings. Terrestrially-derived elements (pollen spores and freshwater algae) were well represented in this interval. The interval also contained abundant mangrove elements, including Acrostichum aureum, Proxapertites cursus, and Psilatricolporites crassus which were found in association with marine elements. The assemblage most likely indicated deposition in open salt marshes, brackish lagoon or nearshore to inner neritic environment. The presence of open marine taxa like Polysphaeridium and Spiniferites suggested strong marine influence during sedimentation. [37] posited that the presence of poorly preserved dinocyts Spiniferites together with foraminiferal test linings indicated close proximity to marginal marine setting. The same interpretation was applicable to Zone III (8200 - 8230 to 7540 $7570 \mathrm{ft}$ ) because of the common occurrence of abundant marine elements.

Zones II and IV fell within the intervals 8530 to $8260 \mathrm{ft}$ as well as 7510 to 6330 $\mathrm{ft}$. The zones were considered to be similar because of the absence of marine elements except for the minor record of one count of Tuberculodinium vancampoae and one count of Leiosphaeridia sp., an acritarch together with 2 counts of undifferentiated dinocysts. The two intervals were marked by abundant record of pollen, spores, freshwater and water edge elements including Laevigatosporites sp. there were also abundant occurrence of mangrove elements including Acrostichum aureum and $Z$. ramonae. The association most likely indicated sedimentation in swamps and fluvial settings. The few counts of marine element in the Zone IV might be the effect of minimal marine influence as a result of tide. [34] reported that tide-dominated delta usually developed extensive mangrove vegetations.

\section{Conclusion}

Palynological study of OSE 1 well in offshore Niger Delta Basin revealed that the stratigraphic interval contained variable low to high diversity assemblages. The 
palynological assemblage was composed of Angiosperm pollen, Pteridophytic spores, dinoflagellates, freshwater algal spores, acritarch and fungal spores. The occurrence of marker species namely Magnatriatites howardi, Crassoretitriletes vanraadshooveni, Pachydemites diederixi, Stereisporites, Verrutricolporites rotundipus, stereisporites sp., and Retistephanocolporites gracilis indicated that the sediments ranged from Early to Late Miocene (Burdigalian-Messinian) age. Some of the identified palynological zones (P720 - P770) were merged because the chronostratigraphic marker species for some of the zones were either absent or were too sparse to permit reliable identification of the boundaries. This observation might suggest erosion or non-preservation of palynomorphs. The major ecological groups (mangrove, freshwater swamps, brackish water swamps, rain forest, savannah) identified indicated prevalence of humid tropical climate in Niger Delta region during Miocene Epoch. The depositional environments included fluvial, freshwater lakes and swamps, brackish lagoon, open salt marshes and inner shoreface settings. Stratigraphic interval with records of marine elements (dinoflagellates) might indicate periods of marine transgressive events. However, further studies such as foraminiferal biostratigraphy and log analysis would be needed to establish this deduction.

\section{Conflicts of Interest}

The authors declare no conflicts of interest regarding the publication of this paper.

\section{References}

[1] Adebayo, O.F. (2013) Palynology of Late Miocene to Pliocene Agbada Formation, Niger Delta Basin, Nigeria. Elixir International Journal of Geoscience, 56, $13370-13373$.

[2] Reijers, T.J.A. (2011) Stratigraphy and Sedimentology of the Niger Delta. Geologos, 17, 133-162. https://doi.org/10.2478/v10118-011-0008-3

[3] Onyekuru, S.O. (2013) Stratigraphy and Petroleum Plays of the Late to Middle Oligocene Sediments in the "XY" Field, Onshore Niger Delta Basin, Nigeria. International Journal of Scientific \& Engineering Research, 4, 627-636.

[4] Rull, V. (2002) Fluvial to Shallow Marine Facies Correlations and Subtle Trap Identification in a Complex Tectonic Setting, High-Impact Palynology in Petroleum Geology: Applications from Venezuela (Northern South America). American Association of Petroleum Geologists Bulletin, 86, 279-300. https://doi.org/10.1306/61EEDAB2-173E-11D7-8645000102C1865D

[5] Adebayo, O.F. and Ojo, A.O. (2014) Miocene-Pliocene Vegetation and Climate Dynamics of the Niger Delta Basin Based on Palynological Signatures. Journal of Environment and Earth Science, 4, 58-67.

[6] Chow, Y.C. (1995) Palynological Climatic Biosignal as a High Resolution Tool for Sequence Stratigraphical Studies, Offshore Sabah and Sarawak, Malaysia. 1-10.

[7] Oboh, F.E. (1992) Middle Miocene Palaeoenvironments of the Niger Delta. Palaeogeography, Palaeoclimatology, Palaeoecology, 92, 55-84.

https://doi.org/10.1016/0031-0182(92)90135-R 
[8] Germeraad, J.H., Hopping, C.A. and Muller, J. (1968) Palynology of Tertiary Sediments from Tropical Areas. Review of Palaeobotany and Palynology, 6, 189-348. https://doi.org/10.1016/0034-6667(68)90051-1

[9] Evamy, B.D., Haremboure, J., Kamerling, P., Knaap, W.A., Molloy, F.A. and Rowlands, P.H. (1978) Hydrocarbon Habitat of Tertiary Niger Delta. American Association of Petroleum Geologists Bulletin, 62, 1-39. https://doi.org/10.1306/C1EA47ED-16C9-11D7-8645000102C1865D

[10] Van Der Zwan, C.J. and Brugnman, W.A. (1999) Biosigals from EA Field, Nigeria. In: Jones, R.W. and Simmons, M.D., Eds., Biostratigraphy in Production and Development Geology, Geological Society, London, Special Publication 152, 291-301. https://doi.org/10.1144/GSL.SP.1999.152.01.16

[11] Demchuk, T.D. and Morley, R.J. (2004) General Palynofloral Characteristics from Nigeria Deepwater Offshore: Chronostratigraphy and Calibration to Sequence Stratigraphy. Palynology, 28, 238-238.

[12] Adebayo, O.F., Orijemie, A.E. and Aturamu, A.O. (2012) Palyology of Bog-1 Well, Southwestern Niger Delta Basin, Nigeria. International Journal of Science and Technology, 2, 214-222.

[13] Ojo, A.O. and Adebayo, O.F. (2012) Palynostratigrapy and Paleoecology of Chev-1 Well, Southwestern Niger Delta Basin, Nigeria. Elixir Geoscience, 43, 6982-6986.

[14] Bankole, S., Schrank, E. and Adeonipekun, P. (2016) Paleoecology of the Neogene Agbada Formation, Niger Delta, Nigeria. Ife Journal of Science, 18, 845-859.

[15] Reijers, T.J.A., Petters, S.W. and Nwajide, C.S. (1997) The Niger Delta Basin, In: Selley, R.C., Ed., African Basins-Sedimentary Basin of the World3, Elsevier Science, Amsterdam, 151-172. https://doi.org/10.1016/S1874-5997(97)80010-X

[16] Mamah, L.I., Okogbue, C.O. and Onuoha, K.M. (2005) Inversion Tectonics of the Benue Trough. Global Journal f Geological Sciences, 2, 163-167. https://doi.org/10.4314/gjgs.v3i2.18723

[17] Doust, H. and Omatsola, E. (1990) Niger Delta. In: Edwards, J.D. and Santogrossi, P.A., Eds., Divergent/ Passive Margin Basins, American Association of Petroleum Geologists Memoir 48, Tulsa, 239-248.

[18] Nyantakyi, E.K., Hu, W.S., Borkloe, J.K., Qin, G. and Han, M.C. (2013) Structural and Stratigraphic Mapping of Delta Field, Agbada Formation, Offshore Niger Delta, Nigeria. American Journal of Engineering Research, 2, 204-215.

[19] Ola, P.S. and Adewale, B.K. (2014) Palynostratigraphy and Paleoclimate of the Sequences Penetrated by Meren 31 Side Tract-2 Well, Offshore Niger Delta. International Journal of Geosciences, 5, 1206-1218. https://doi.org/10.4236/ijg.2014.510100

[20] Dim, C.I.P. (2017) Hydrocarbon Prospectivity in the Eastern Coastal Swamp Depo-Belt of the Niger Delta Basin. Springer Briefs in Earth Sciences, Berlin, Chapter 2, 9-16. https://doi.org/10.1007/978-3-319-44627-1_2

[21] Avbobvo, A.A. (1978) Tertiary Lithostratigraphy of Niger Delta. American Association of Petroleum Geologists Bulletin, 62, 295-306. https://doi.org/10.1306/C1EA482E-16C9-11D7-8645000102C1865D

[22] Short, K.C. and Stauble, A.J. (1967) Outline of Geology of Niger Delta. American Association of Petroleum Geologists Bulletin, 51, 761-779. https://doi.org/10.1306/5D25C0CF-16C1-11D7-8645000102C1865D

[23] Ejedawe, J.E., Coker, S.J.L., Lambert-Aikhionbare, D.O., Alofe, K.B. and Adoh, F.O. (1984) Evolution of Oil-Generative Window and Oil and Gas Occurrence in Tertiary Niger Delta Basin. American Association of Petroleum Geologists Bulletin, 68, 
1744-1751. https://doi.org/10.1306/AD46198F-16F7-11D7-8645000102C1865D

[24] Chukwu, G.A. (1991) The Niger Delta Complex Basin: Stratigraphy, Structure and Hydrocarbon Potential. Journal of Petroleum Geology, 14, 211-220.

https://doi.org/10.1111/j.1747-5457.1991.tb00363.x

[25] Traverse, A. (2007) Palaeopalynology. 2nd Edition, Springer, Berlin, 811 p.

[26] Rao, M.R., Sahni, S., Rana, R.S. and Verma, P. (2013) Palynostratigraphy and Depositional Environment of Vastan Lignite Mine (Early Eocene), Gujarat, Western India. Journal of Earth System Science, 122, 289-307.

https://doi.org/10.1007/s12040-013-0280-4

[27] Clarke, B.T. and Fredderikson, N.O. (1968) New Sporomorphs from Upper Tertiary of Nigeria. Graha Palynologica, 8, 210-224. https://doi.org/10.1080/00173136809427466

[28] Rull, V. (2001) A Quantitative Palynological Record from the Early Miocene of Western Venezuela, with Emphasis on Mangroves. Palynology, 25, 109-126. https://doi.org/10.2113/0250109

[29] Massini-García, J.L., Jacobs, B.F., Pan, A., Tabor, N. and Kappelman, J. (2006) The Occurrence of the Fern Acrostichum in Oligocene Volcanic Strata of the Northwestern Ethiopian Plateau. International Journal of Plant Sciences, 167, 909-918. https://doi.org/10.1086/504390

[30] Ige, O.E. (2009) A Late Tertiary Pollen Record from Niger Delta, Nigeria. International Journal of Botany, 5, 203-215. https://doi.org/10.3923/ijb.2009.203.215

[31] Lorente, M.A. (1986) Palynology and Palynofacies of the Upper Tertiary in Venezuela. Dissertationes Botanicae, Band 99, Lubrecht \& Cramer Ltd., Port Jervis.

[32] Durugbo, E.U., Ogundipe, O.T. and Ulu, O.K. (2011) Preliminary Reports on Middle Miocene-Early Pleistocene Dinoflagellate Cysts from the Western Niger Delta, Nigeria. Ozean Journal of Applied Sciences, 4, 2011.

[33] Morley, R.J. (1991) Tertiary Stratigraphic Palynology in Southeast Asia: Current Status and New Directions. Bulletin of the Geological Society of Malaysia, 28, 1-36.

[34] Elsawi, A. and Schrank, E. (2008) Upper Cretaceous to Neogene Palynology of the Melut Basin, Southeastern Sudan. Palynology, 32, 101-129.

https://doi.org/10.2113/gspalynol.32.1.101

[35] Jolley, D.W. and Whitham, A.G. (2004) A Stratigraphical and Paleoenvironmental Analysis of Sub Basaltic Paleogene Sediments of East Greenland. Petroleum Geos cience, 10, 53-60. https://doi.org/10.1144/1354-079302-511

[36] Morley, R.J. (1996) Biostratigraphic Characterization of Systems Tracts in Tertiary Sedimentary Basins. Proceeding of the International Symposium on Sequence Stratigraphy in SE Asia, Jakarta, May 1996, 49-71.

[37] El-Beialy, S.Y. (1998) Stratigraphic and Paleoenvironmental Significance of Eocene Palynomorphs from the Rusayi Shale Formation, Al Khawd, Northern Oman. Review of Palaeobotany and Palynology, 102, 249-258. 
Appendix 1. Frequency and Percentage Pollen and Spores from OSE 1 Well, Niger Delta

\begin{tabular}{|c|c|c|c|c|c|c|c|}
\hline $\mathrm{S} / \mathrm{N}$ & Depth (ft) & Pollen (P) & Spore (S) & Total $(\mathrm{P}+\mathrm{S})$ & $\% \mathrm{P}$ & $\% \mathrm{~S}$ & $\mathrm{P} / \mathrm{S}$ \\
\hline 1 & $6330-6360$ & 18 & 16 & 34 & 52.94 & 47.06 & 1.13 \\
\hline 2 & $6390-6420$ & 10 & 10 & 20 & 50.00 & 50.00 & 1.00 \\
\hline 3 & $6450-6480$ & 11 & 6 & 17 & 64.71 & 35.29 & 1.83 \\
\hline 4 & $6510-6540$ & 3 & 7 & 10 & 30.00 & 70.00 & 0.43 \\
\hline 5 & $6570-6600$ & 1 & 1 & 2 & 50.00 & 50.00 & 1.00 \\
\hline 6 & $6630-6660$ & 7 & 5 & 12 & 58.33 & 41.67 & 1.40 \\
\hline 7 & $6690-6720$ & 9 & 3 & 12 & 75.00 & 25.00 & 3.00 \\
\hline 8 & $6750-6780$ & 1 & 3 & 4 & 25.00 & 75.00 & 0.33 \\
\hline 9 & $6810-6840$ & 3 & 4 & 7 & 42.86 & 57.14 & 0.75 \\
\hline 10 & $6870-6900$ & 5 & 5 & 10 & 50.00 & 50.00 & 1.00 \\
\hline 11 & $6930-6960$ & 10 & 4 & 14 & 71.43 & 28.57 & 2.50 \\
\hline 12 & $6990-7020$ & 6 & 4 & 10 & 60.00 & 40.00 & 1.50 \\
\hline 13 & $7050-7080$ & 8 & 7 & 15 & 53.33 & 46.67 & 1.14 \\
\hline 14 & $7120-7150$ & 1 & 1 & 2 & 50.00 & 50.00 & 1.00 \\
\hline 15 & $7180-7210$ & 4 & 5 & 9 & 44.44 & 55.56 & 0.80 \\
\hline 16 & $7240-7270$ & 2 & 1 & 3 & 66.67 & 33.33 & 2.00 \\
\hline 17 & $7300-7330$ & 7 & 11 & 18 & 38.89 & 61.11 & 0.64 \\
\hline 18 & $7360-7390$ & 2 & 3 & 5 & 40.00 & 60.00 & 0.67 \\
\hline 19 & $7420-7450$ & 44 & 15 & 59 & 74.58 & 25.42 & 2.93 \\
\hline 20 & $7480-7510$ & 4 & 3 & 7 & 57.14 & 42.86 & 1.33 \\
\hline 21 & $7540-7570$ & 4 & 2 & 6 & 66.67 & 33.33 & 2.00 \\
\hline 22 & $7600-7630$ & 2 & 1 & 3 & 66.67 & 33.33 & 2.00 \\
\hline 23 & $7660-7690$ & 5 & 1 & 6 & 83.33 & 16.67 & 5.00 \\
\hline 24 & $7720-7750$ & 2 & 2 & 4 & 50.00 & 50.00 & 1.00 \\
\hline 25 & $7780-7810$ & 1 & 1 & 2 & 50.00 & 50.00 & 1.00 \\
\hline 26 & $7840-7870$ & 2 & 1 & 3 & 66.67 & 33.33 & 2.00 \\
\hline 27 & $7900-7930$ & 2 & 1 & 3 & 66.67 & 33.33 & 2.00 \\
\hline 28 & $7960-7990$ & 0 & 3 & 3 & 0.00 & 100.00 & 0.00 \\
\hline 29 & $8020-8050$ & 2 & 1 & 3 & 66.67 & 33.33 & 2.00 \\
\hline 30 & $8080-8110$ & 6 & 1 & 7 & 85.71 & 14.29 & 6.00 \\
\hline 31 & $8140-8170$ & 5 & 1 & 6 & 83.33 & 16.67 & 5.00 \\
\hline 32 & $8200-8230$ & 2 & 0 & 2 & 100.00 & 0.00 & - \\
\hline 33 & $8260-8290$ & 7 & 6 & 13 & 53.85 & 46.15 & 1.17 \\
\hline 34 & $8320-8350$ & 6 & 7 & 13 & 46.15 & 53.85 & 0.86 \\
\hline 35 & $8380-8410$ & 4 & 9 & 13 & 30.77 & 69.23 & 0.44 \\
\hline
\end{tabular}


O. A. Ogbahon

\begin{tabular}{lccccccc}
\multicolumn{1}{l}{ Continued } & \multicolumn{7}{l}{} \\
\hline 36 & $8440-8470$ & 5 & 5 & 10 & 50.00 & 50.00 & 1.00 \\
37 & $8500-8530$ & 5 & 2 & 7 & 71.43 & 28.57 & 2.50 \\
38 & $8560-8590$ & 7 & 5 & 12 & 58.33 & 41.67 & 1.40 \\
39 & $8620-8650$ & 1 & 3 & 4 & 25.00 & 75.00 & 0.33 \\
40 & $8680-8710$ & 1 & 1 & 2 & 50.00 & 50.00 & 1.00 \\
41 & $8740-8770$ & 6 & 6 & 12 & 50.00 & 50.00 & 1.00 \\
42 & $8770-8800$ & 2 & 3 & 5 & 40.00 & 60.00 & 0.67 \\
43 & $8800-8890$ & 7 & 21 & 28 & 25.00 & 75.00 & 0.33 \\
44 & $8920-8950$ & 7 & 26 & 33 & 21.21 & 78.79 & 0.27 \\
45 & $8980-9010$ & 4 & 8 & 12 & 33.33 & 66.67 & 0.50 \\
\hline
\end{tabular}

